\title{
Students' worksheet validity based on contextual teaching and learning in junior high school
}

\author{
Arnilawati ${ }^{1}$, Armiati $^{2}$, Edwin Musdi $^{3}$ \\ ${ }^{123}$ Universitas Negeri Padang, Padang - Indonesia, (arnilawati1812@gmail.com)
}

\begin{abstract}
This research was derived from the low ability of students' problem solving. One of the factors was the students didn't understand the problem of mathematics related to real life and the development of learning media like students' worksheet had not been optimal yet in school. One of the efforts done was by using students' worksheet based on Contextual Teaching and Learning (CTL). The purpose of this research is to describe the characteristics of mathematical worksheet based on CTL to improve the problem solving ability of students in junior high school that fulfills the criteria of valid. This research used plomp development model. The plomp model consists of three phases, namely preliminary research, prototyping and assessment phase. Based on the development done, it could be obtained students' worksheet based on CTL in junior high school valid.
\end{abstract}

Keywords: students'worksheet, contextual, problem solving

This is an open access article distributed under the Creative Commons 4.0 Attribution License, which permits unrestricted use, distribution, and reproduction in any medium, provided the original work is properly cited. $\mathrm{C} 2018$ by author and Faculty of education, Universitas Negeri Padang.

\section{Introduction}

Mathematics is one of the subjects taught at all levels of education that has an important role in the development of mathematical ability of learners. Through mathematical ability, learners can understand and identify the existing problems, and find solutions from the problems provided. One of the mathematical skills that play an important role in the success of learners is the ability to solve problems itself.

According Sari (2014) stated that the problem solving ability in learning mathematics can be viewed as a goal that must be achieved. Correspondingly, Sari (2015) states that problem-solving abilities are the abilities that currently are the main focus in mathematics learning in many countries. Important awareness of problem solving skills is also evident in Indonesia, where since the Curriculum of 2004 (KBK), Indonesia has incorporated problem-solving skills as one of the goals in mathematics learning. In completion of the problem solving, learners are required to meet the problem solving indicators. Some of the problem-solving indicators according to NCTM (2000) are as follows: 1) identify known, questioned elements and the adequacy of the required elements; 2) formulate math problems or develop mathematical models; 3) implementing strategies to solve problems; 4) explain or interpret the results according to the original problem; 5) using mathematics meaningfully. However, mathematics learning in Indonesia from year to year has not shown significant progress especially on problem solving ability.

Problems in mathematics learning are also seen when researchers conducted observations at MTsN 6 Padang on 19 and 20 August 2016. The researcher gives a test of mathematics problem 
solving ability to the students of class VIII12 in MTsN Model Padang. Based on the results of the problem-solving test, it can be seen that the percentage of each problem solving indicator on each highest scale has not reached the ideal score.

Another problem that is found when the researcher makes observations is the learning devices used by teachers to enable and improve the problem solving skills of learners is not yet available. One such learning tool is LKPD (Students Worksheet). According to Prastowo (2011: 204), "LKPD is not an abbreviation of the activity sheet of learners, but the students' work sheet, that is teaching materials that have been packaged in such a way, so that learners are expected to learn the teaching materials independently. Based on the results of these opinions, then LKPD can be used as a guideline, so that learners can actively engage in learning activities besides LKPD also used to help and lead learners to construct knowledge in order to learners can find the concept. From the results of interviews with mathematics teachers, this problem occurs because of the limitations of teachers to create and meet the needs of learners in the process of learning mathematics. The designed LKPD does not meet the needs of learners to actively involve them in learning, either individually or in groups. The material contained in LKPD designed by the teacher has not been presented in a contextual context in building student knowledge, motivation, and opportunities in finding the concept of mathematics.

It is also the underlying researcher choosing the development of LKPD based on CTL. Preparation of LKPD based on CTL is very possible to direct learners to solve mathematical problems in order to improve their problem solving skills of mathematics. The ability will equip learners to make connections between their existing knowledge and new information that its application is in the context of everyday life. A good LKPD in learning mathematics will provide learners the widest opportunity so they can be able to develop their creativity in solving some problem.

\section{Method}

A Plomp model was the development model which was used in this reserch. It is consisting of three phases, namely preliminary research, prototyping and assessment phase. This article only discusses the prototype stage of LKPD validation. In the preliminary study, needs analysis, curriculum analysis, concept analysis and analysis of learners were conducted. Data collection techniques were done through observation, interviews with math teachers, questionnaires and initial tests with students of class VIII MTsN 6 Padang.

The prototype-making phase was done by designing a CTL-based mathematical LKPD. The LKPD was developed based on Tessmer's formative evaluation. This evaluation consists of self-evaluation, expert validation, individual evaluation, small group evaluation and field testing. LKPD that has been developed validated by 5 experts who are called as validator, consists of 3 mathematics education experts, one of the educational technology experts and one of Indonesian language expert. The validator provided assessment and suggestions on the learning tools that has been designed to determine the weaknesses and strengths, and taking into account the expected product specifications using validation sheets.

Data analysis techniques used in this study were analyzed descriptively. In the preliminary study, the data collection instruments were in the form of needs analysis sheet, curriculum, learners and concepts, observation sheet and interview guide. Validity analysis was performed on data obtained from the results of the validation instrument. The valid instrument includes self evaluation instruments and validation instruments.

\section{Results and Discussion}

In the preliminary study, needs analysis, curriculum analysis, concept analysis and analysis of learners were conducted. Needs analysis was done to get information about the problems contained 
in the school's learning both faced by teachers and learners. Information gathering was conducted by conducting interviews with teachers, observing the implementation of learning, and questionnaires of learners. Meanwhile, initial tests was conducted to see the ability of learners. Initial tests were conducted on the problem-solving ability of learners with the instrument in the form of problems that are tailored to the indicators of problem-solving ability.

The curriculum analysis aims to analyze the curriculum of two supporting aspects ie KI (Kompetensi Inti / Core Competencies) and KD (Kompetensi dasar / Basic Competencies). At this stage, a review of the curriculum of 2013 for the subjects of mathematics class VIII SMP was conducted. The 2013 curriculum analysis was derived from the mathematics syllabus of SMP / MTs Class VIII in the first semester. This analysis was conducted to study the material coverage, learning objectives, and materials that can be used in CTL.

Conceptual analysis is the identification of the materials that will be discussed in the learning. These materials are arranged systematically by linking a concept with another relevant concept to form a concept. This analysis aims to determine the content and subject matter that can be presented on CTL-based LKPD. The content and subject matter are tailored to the existing components of CTL.

Student analysis was done to examine the characteristics of the students in class VIII SMP. This analysis is used as a consideration in designing LKPD based on CTL which includes the way of students' learning, students' participation, the importance of LKPD for learners, and LKPD description which learners enjoy. So that the resulting LKPD is in accordance with the characteristics possessed. In this study, students who will be used as subjects are students of class VIII SMP.

The prototype-making phase begins with designing a LKPD based on CTL. This design is called prototype 1. This LKPD design is based on preliminary research results that have been done. After the LKPD based on CTL was produced, self-evaluation by the researcher was done for the construct validity and discuss with the experts for content validity. Validation content of CTL-based LPKP was done by 5 experts consisting of 3 experts Mathematics Education, 1 language expert and 1 educational technology expert.

Content validity means conformity between the products produced with some specified criteria, conformity with the contents of the applicable curriculum, the suitability of the learning device with the syllabus, and the suitability of the device with the learning objectives. While the validity construct means the suitability between the products produced with the development elements that have been set. The construct validity of CTL-based LKPD was obtained through the preparation of devices based on the intended subject characteristics or the expected behavior of the subject.In self evaluation, the errors on LKPD that were found by researchers include typing errors and punctuation errors. After self-evaluation, the CTL-based LKPD is validated by the validator. Based on the findings of errors in self evaluation and validator suggestions, then the improvements LKPD based CTL were perfomed as follows: 
Table 1. Revision LKPD

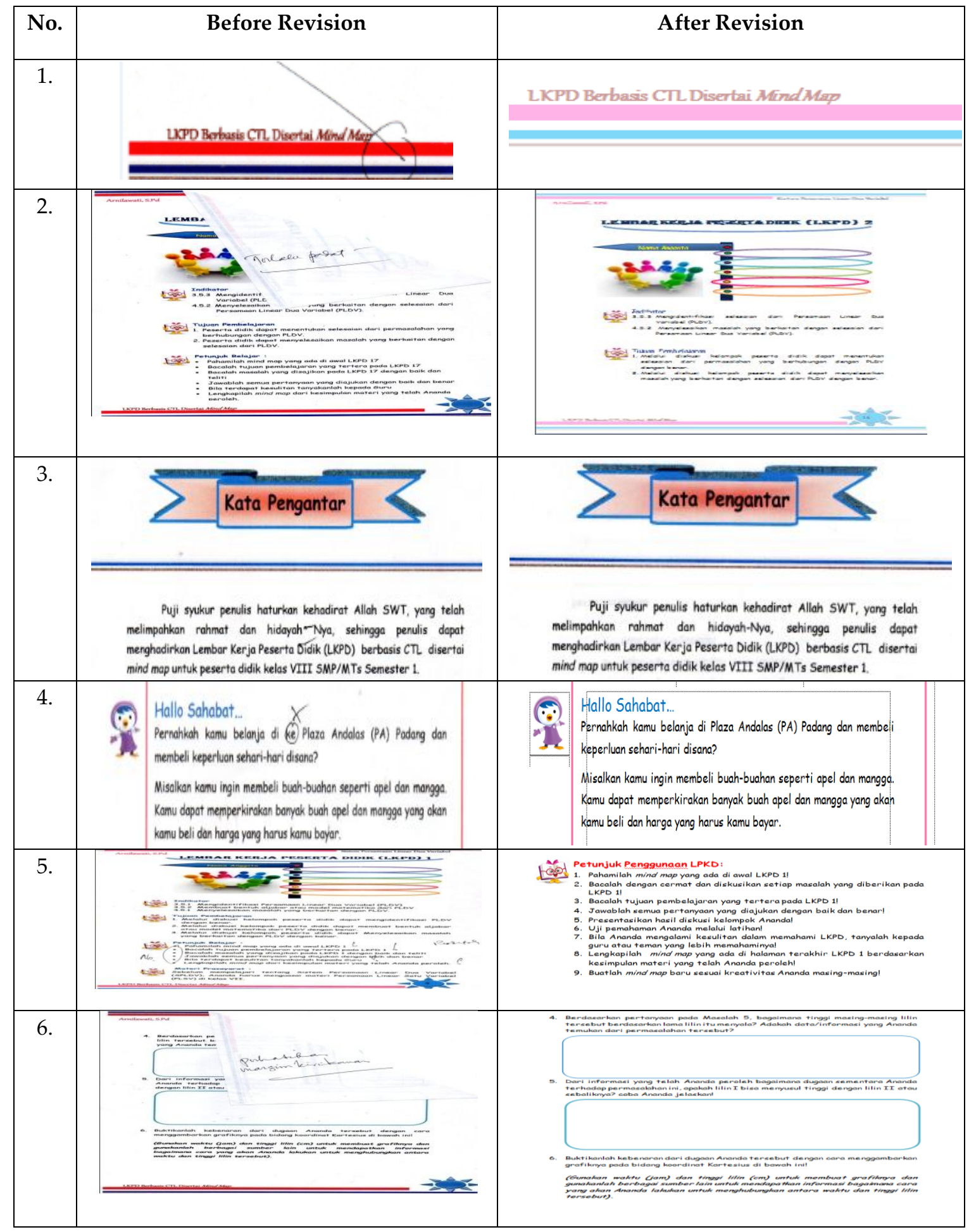

After the repairs were made, the validators provided an assessment of LKPD. Overall CTL-based LKPD validated by math experts has met valid criteria with a validity index of 0.85 , this means LKPD characteristics and conformance with CTL-based learning can help learners to improve their mathematical problem-solving abilities. The next aspect is the aspect of graphics or display. This aspect of graphics or display was validated by one lecturer of Educational Technology. The average from the data analysis of graphical or display aspect validation results was 0.67 with valid category, thus the aspect of graphics or display is valid. The last aspect that was validated was the language 
aspect. This language aspect was validated by one Indonesian lecturer. From data analysis of validation result of aspect of language, it was obtained validity index of 0,81 with valid criterion, this means that language used in LKPD have been communicative and have valid. The results of the overall validation on each aspect can be seen in Table 2 .

Table 2. The Overall LKPD Validation Results

\begin{tabular}{clc}
\hline No & \multicolumn{1}{c}{ Aspect of the Assessed } & Validity Index \\
1. & Presentation & 0,84 \\
2. & Eligibility of content & 0,86 \\
3. & Chart or display & 0,67 \\
4. & Language & 0,81 \\
& Average of Validity Index & $\mathbf{0 , 7 9}$ \\
& Criteria & Valid \\
\hline
\end{tabular}

Based on Table 2 it can be seen that the average LKPD validation as a whole is 0.79 with valid criteria. Thus, it can be concluded that LKPD with CTL-based learning has been valid.

\section{Conclusions}

Based on the validation results, the information obtained is that the development and design has produced CTL-based mathematics LKPD to improve the problem-solving ability of students in junior high school that meets the valid criteria.

\section{Acknowledgments}

The authors wish to thank Dr. Armiati, M.Pd. and Dr. Edwin Musdi, M.Pd. as supervisors and lecturers of Universitas Negeri Padang who have provided guidance in the completion of the article. Subsequently to the principal and teachers of mathematics at MTsN 6 Padang who have allowed and facilitated the authors to conduct research trials. This article is compiled based on a thesis written by Arnilawati entitled "Development of Mathematics Learning Tool based on Contextual Teaching and Learning (CTL) with Mind Map on Material of Semester 1 Class VIII SMP / MTs".

\section{References}

Sari, Trina Novi. (2014). Implementasi Pendekatan Contextual Teaching and Learning (CTL) Bernuansa Pendidikan Karakter untuk Meningkatkan Kemampuan Pemecahan Masalah Matematis Siswa MTsN. Jurnal Didaktik Matematika Volume 1 Nomor 1 April 2014.

Sari, Nenden Mutiara. (2015). "Meningkatkan Kemampuan Pemecahan Masalah Matematis Dengan Metode Eksplorasi. Journal Mathematics Education. Department of Mathematics Education, UMP Purwokerto.

National Council of Teacher Mathematics. (2000). Principles and Standards for Schools Mathematics. USA: Reston.

Prastowo, Andi. (2011). Panduan Kreatif Membuat Bahan Ajar Inovatif. Jogjakarta: DIVA Press. 